\title{
Globalization and new policy concerns: the WTO and the EU's sustainability criteria for biofuels
}

Article

Accepted Version

Daugbjerg, C. and Swinbank, A. (2014) Globalization and new policy concerns: the WTO and the EU's sustainability criteria for biofuels. Journal of European Public Policy, 22 (3). pp. 429446. ISSN 1466-4429 doi:

https://doi.org/10.1080/13501763.2014.927520 Available at https://centaur.reading.ac.uk/37044/

It is advisable to refer to the publisher's version if you intend to cite from the work. See Guidance on citing.

Published version at: http://www.tandfonline.com/doi/full/10.1080/13501763.2014.927520\#.U7E7ZO_Qd9A

To link to this article DOI: http://dx.doi.org/10.1080/13501763.2014.927520

Publisher: Taylor \& Francis

All outputs in CentAUR are protected by Intellectual Property Rights law, including copyright law. Copyright and IPR is retained by the creators or other copyright holders. Terms and conditions for use of this material are defined in the End User Agreement.

www.reading.ac.uk/centaur 
Central Archive at the University of Reading

Reading's research outputs online 


\title{
Globalization and new policy concerns:
}

\section{The WTO and the EU's sustainability criteria for}

\section{biofuels}

\section{Carsten Daugbjerg and Alan Swinbank}

\begin{abstract}
The transfer of some decision-making authority from the domestic to the supranational arena as a result of the establishment of the World Trade Organization (WTO) in 1995 potentially changed domestic policy dynamics. The WTO agreements reflect the trade policy concerns addressed in the Uruguay Round in the late 1980s and early 1990s. This article applies and adapts historical institutionalism to explain how international organizations may constrain and facilitate certain domestic policy options. It demonstrates that, while the WTO legal framework has become more receptive of environmental sustainability concerns, the social sustainability concerns that were increasingly entering the debate over biofuel policies were not easily accommodated, and this was seen as a constraint on the content of the European Union's (EU) policy adopted in 2009. Only the environmental dimension of a broader concept of sustainability was included in the policy design.
\end{abstract}

KEY WORDS: biofuel, European Parliament, globalization, institutions, sustainability, WTO. 


\section{INTRODUCTION}

The establishment of the WTO in 1995 marked the beginning of a new phase in globalization by transferring some decision-making authority from the domestic to the supranational arena. Skogstad (2000: 808) refers to this transfer of authority as political globalization, which she defines as the 'restructuring of power relations with the emergence of new supranational centres of political authority.' A key question within the emerging literature on global public policy (e.g. Skogstad 2011; Stone 2008) is whether this transfer of decision-making authority affects domestic policy processes and policy designs. Do domestic policy makers internalize the additional international layer of constraints and opportunities in domestic policy making? We use the case of EU biofuels policy to explore these questions. While the biofuels policy has a trade dimension, it is not predominately a trade policy. Rather, it is a renewable energy policy mainly aimed at lowering greenhouse gas (GHG) emissions, but also at increasing energy security and strengthening the rural economy. Therefore, it is a suitable case for establishing whether the impact of WTO induced political globalization on domestic policy making reaches beyond trade policy.

Biofuels, and the raw materials from which biofuels are made, are tradable, and subject to the same WTO rules that apply to other goods. This is particularly problematic for the EU's biofuels policy as it attempts to strike a difficult balance between encouraging domestic production whilst at the same time achieving the goal that, by $2020,20 \%$ of the EU's overall energy consumption should be provided by renewable resources (European Parliament and Council 2009). For the transport sector $10 \%$ of fuel consumption should be renewable, with sustainable biofuels the most likely source. Quite what is meant by 'sustainable' is a contested issue. Economists tend to focus on an all inclusive approach. Stern (2007: 48) for 
example suggests that 'sustainable development' means that 'future generations should have a right to a standard of living no lower than the current one'. Others adopt more specific criteria. The Roundtable on Sustainable Biofuels (2010), for example, lists twelve 'Principles $\&$ (associated) Criteria for Sustainable Biofuel Production'. Only two of these- on significant reductions in GHG emissions, and avoiding 'negative impacts on biodiversity, ecosystems, and conservation values'-are directly addressed by the EU's biofuel sustainability criteria. Others, such as respecting land-use rights, ensuring 'the human right to adequate food and improve[d] food security in food insecure regions', and not violating human rights or labour rights, are not. We refer collectively to these latter aspects as social sustainability criteria.

The Uruguay Round (UR) of trade negotiations (1986-95) under the General Agreement on Tariffs and Trade (GATT) expanded the trade agenda to include new and difficult issues including non-tariff barriers behind the border. However, there were also limits to the extension of the WTO's coverage. Although the Havana Charter agreed in 1948, that would have established the stillborn International Trade Organization, would have disciplined 'unfair labour conditions', such disciplines never became a part of the GATT or WTO agenda (Gonzalez-Garibay 2011: 172-175). Environmental concerns were growing in the late 1980s and early 1990s, but disciplines for domestic environmental policy measures were not a prioritized topic in the UR; and soon became sidelined in the subsequent Doha Round that began in 2001 (Tarasofsky and Palmer 2006). The UR resulted in a revised Dispute Settlement Understanding (DSU), ousting the old system that had tried to resolve disputes by consensus, and installing instead a new quasi-judicial procedure that WTO Members could not easily block (Goldstein and Steinberg 2008), making it difficult for WTO Members to escape the increased level of political globalization. 
In this article we adopt an institutional perspective on globalization and argue that, as with domestic institutions, global institutions facilitate certain policy options while constraining others and thus influence the way in which domestic policy is shaped. WTO constraints potentially apply at a number of stages in the domestic policy process, and in different ways. Hay and Rosamond (2002: 150) distinguish between three types of globalization effects: ‘(i) the effects of globalization itself; (ii) the effects of having internalized popular constructions of globalization; and ... (iii) the strategic and disingenuous appeal to globalization as a convenient justification for unpalatable reforms.' As to the first, Daugbjerg and Swinbank (2009) for example argued that WTO negotiations were important pressures for reform of the EU's once notorious agricultural policy; and Poletti and De Bièvre (2014) explain how the EU responds to challenges to its domestic policy brought through the WTO's DSU. De Ville (2012: 714) has shown that perceptions of how WTO rules might be applied in some future dispute have been used 'as a rhetorical device that enables actors to pursue their preferences.' In this article we address Hay and Rosamond's second type of globalization effect by demonstrating that the perception that the WTO legal framework was a real constraint influenced the content of the sustainability criteria built into the EU's biofuels policy. Ackrill and Kay (2011) and Lydgate (2012) report that social concerns were left out of the mandatory requirements in order to ensure WTO compatibility. But was this just a rhetorical justification for this particular policy choice, or were key actors persuaded of the reality of a WTO constraint? A threat has to have some credibility, or it will have no leverage in the domestic policy debate. Although the counter factual can never be rigorously established, we demonstrate that policy makers in the European Parliament (EP) were persuaded of a WTO constraint and did actually exercise self-restraint: they were subject to what Lydgate (2012: 160) describes as regulatory chill. 
To establish the extent of 'regulatory chill', this article proceeds in three steps. First, applying historical institutionalism we suggest that the globalization of public policies may lead to an increased number of constraints and opportunities becoming embedded in domestic policy making. Second, the article demonstrates that the sustainability concerns raised by the biofuels debate were not reflected in the WTO rules agreed in the 1990s and therefore were not easily dealt with by the WTO. The penultimate section demonstrates that the sustainability criteria built into the EU biofuels policy were developed in the shadow of WTO constraints, resulting in the inclusion of environmental, but the exclusion of social criteria.

\section{GLOBAL INSTITUTIONS AND DOMESTIC POLICY-MAKING}

There is already an extensive literature on the political consequences of globalization which is often seen to put pressure on states to reform institutions and liberalize policies (e.g. Hay 2006). Research has been undertaken on the emergence of transnational networks; on how international norms developed in such networks impact on domestic public policies (e.g. Stone 2008; Haas 1992; Finnemore and Sikkink 1998); and on how globalization has changed the broader nature of the state (Cerny 1997). Whilst the literature on these issues is now at an advanced level, public policy scholars have made less progress on the global dynamics affecting domestic policy making processes. One reason for this is that the globalization literature pays limited attention to institutional aspects of political globalization. In this article we argue that historical institutionalism has much to offer in understanding how international institutions enable certain domestic policy decisions whilst precluding others: in particular in directing attention to the importance of time in institutionalized political globalization processes. However, the historical institutionalist literature says very little about 
the dynamics that embed global institutional constraints and opportunities into domestic policy making.

Whilst institutions have been defined in various ways, there seems to be a shared view that they are formal or informal rules, norms, codes, etc., that constrain and facilitate certain types of human action (e.g. North 1990; March and Olsen 1989). The notion of path dependency is often used to describe the trajectory of institutional development. The timing and sequencing of events in the formative phases are seen as crucial for the way in which the institution will crystallize. When the course is set, further moves in the same direction reinforce the path as positive feedbacks increase the benefits of pursuing a particular course and increase the costs of switching to alternative courses of action (e.g. Pierson 2000b, North 1990). Hence, institutions embody a historical legacy that shapes outcomes, privileging some policy options over others (see e.g. Pierson 2000a: 264-65).

Historical institutionalism has made substantial contributions to our understanding of the development of domestic institutions and their impact on policies. It has been convincingly demonstrated that institutions have an important impact on the way in which public policies are formulated, their specific shapes and how they are implemented. Fioretos (2011) argues historical institutionalism may have considerable potential to explain the origins, shape and consequences of international institutions. Institutions reflect the concerns of their designers in the specific time period in which they were formed. Thus, the historical legacy of international institutions is important to take into consideration when analysing the contemporary policy consequences of political globalization. As pointed out by Pierson (2000a: 263), 'The necessary conditions for current outcomes occurred in the past'. Like domestic institutions, global organizations reflect the agenda of the time period in which they 
were formed, thus institutionalising certain policy agendas, suppressing others, and developing standard responses to policy problems.

International institutions are particularly disposed to institutionalize certain policy agendas and develop path dependency since they have large set-up costs (see Pierson 2000a: 254) and are difficult to change as a result of the consensual decision-making rule applied by most international organizations. Consensus is achieved through a process of diplomatic negotiations in which reciprocity is the standard procedure for reaching agreement. When a large number of parties take part in negotiations, the whole exercise can become extremely complex and may provoke severe controversies (Keohane 1986), or even deadlock.

However, the policy agendas of international institutions rarely 'freeze' completely. As Streeck and Thelen (2005: 24) point out, 'institutions require active maintenance; to remain what they are they need to be reset and refocused, or sometimes more fundamentally recalibrated and renegotiated, in response to the political and economic environment in which they are embedded.' This is likely to produce bounded change (Pierson 2000a: 265) in which change will be limited to adjustments within the broader policy framework.

To explain the dynamics that embed global institutional constraints and opportunities into domestic policy making, historical institutionalism cannot stand alone as the sole analytical framework. It needs to be supplemented by conceptual tools applied in policy studies to explain how the constraints and opportunities embodied in global institutions influence domestic policy processes. Coleman and Perl (1999: 698) argue that in the 'period of globalization, the balance among social forces is frequently changing, resources are being redistributed, and ways of thinking and well-used recipes are being challenged'. This may 
challenge well-established domestic policy institutions (policy communities) by altering their policy agenda, rebalancing power relations within these institutions, or lead to their destruction (ibid.). Whether established domestic policy institutions can survive partial transfer of authority from national to international institutions is an empirical question, but it is likely to lead to a restructuring of policy opportunity structures. Some domestic policy agendas will be privileged, while others will be weakened, enabling the adoption of some domestic policy measures at the expense of others.

EU biofuels policy making, particularly in the EP, provides an illuminating example of the processes through which global institutions impact on domestic policy making. On one hand, the time-dependent lock-in of WTO trade rules relating to social sustainability, particularly land rights and labour conditions, constrained actors with these concerns. On the other hand, the reinterpretation of the WTO trade rules relating to environmental regulations that had taken place through dispute settlement enabled a trade-related environmental policy agenda to be pursued in the policy process leading to the adoption of the EU's biofuels policy in 2009.

\section{INSTITUTIONALIZING WTO TRADE RULES}

The WTO was the outcome of the UR negotiations and was a continuation of the embedded liberalism originally underpinning the GATT (Ruggie 1982). The overall decision-making rules in the UR were: i) that of the Single Undertaking, usually phrased as 'nothing is agreed until everything is agreed', and ii) consensus. This meant that all participating states had to agree on all aspects of the package of agreements before a deal could be concluded. There is currently a paralysis in the WTO's legislative role, as exemplified by the failure to either complete, or scrap, the Doha Round (despite the mini-success of the Bali Ministerial in 
December 2013). Its membership has expanded, new states, and groups of states - in particular the G20 lead by Brazil, India and China - have emerged as key players, and new trade concerns have emerged (e.g. those focussed on biofuels). This has made concluding the Doha Round as a Single Undertaking very difficult, demonstrating that consensual decisionmaking rules and the Single Undertaking in international organizations make institutional change extremely problematic. This has effectively locked-in the initial institutional design agreed in the UR.

However, the WTO's day-to-day activities continue as normal. Through the DSU, its semijudicial role remains, and WTO Members continue to arbitrate their different interpretations of WTO Agreements before the Dispute Settlement Body. As in most judicial systems, there seems to have been an evolution of the rules. Indeed Goldstein and Steinberg (2008: 257) concluded that 'there has been a surprising amount of judicial lawmaking' by the Appellate Body 'through interpretation of unclear rules and the filling of gaps in WTO agreements'. Thus panel and Appellate Body reports become part of the WTO's case history, and the precedents they establish are cited in subsequent disputes. Cases involving biofuels, and renewable energy more generally, will likely figure in future disputes, particularly where the existing WTO Agreements-locked-in to the prevailing concerns of the 1980s-do not reflect the circumstances of today, leading to yet more judicial law-making.

\section{Sustainability criteria and WTO trade rules}

The sustainability criteria discussed in this article are what are frequently referred to as nonproduct-related process and production methods (npr-PPMs): that is they leave no physical traces in the end product. Bioethanol produced in a sustainable way is physically indistinguishable from the non-sustainable product. The WTO legal system has been loath to 
admit that it would be legitimate to use npr-PPMs to differentiate between products. The first hurdle is GATT Article III, which addresses national treatment. Products imported from other WTO Members should not be accorded treatment less favourable to that accorded to like products of national origin 'in respect of all laws, regulations and requirements affecting their internal sale, offering for sale, purchase, transportation, distribution or use' and in terms of 'internal taxes and other internal charges'.

Policy measures that might prove inconsistent with GATT provisions (including Article III) can nonetheless be saved by GATT Article XX: nothing in the GATT Agreement should 'prevent the adoption or enforcement' of a series of measures including those 'necessary to protect human, animal or plant life or health', and those 'relating to the conservation of exhaustible natural resources if such measures are made effective with restrictions on domestic production or consumption'. The Article XX defence had, however, been rather problematic in past attempts to defend environmentally-motivated legislation.

The WTO Agreement on Technical Barriers to Trade (TBT) introduced additional disciplines. In particular it seeks to ensure that both regulations (policy measures with which compliance is mandatory) and standards (policy measures with which compliance is voluntary) 'do not create unnecessary obstacles to international trade'. There had, however, been some debate over the relevance of the TBT Agreement, with some authors arguing that it does not apply to npr-PPMs, whilst others claimed it does (Norpoth, 2013: 579-80). In language similar to the chapeau to GATT Article XX, the TBT Agreement (Article 2.2) stipulates that 'technical regulations shall not be more trade-restrictive than necessary to fulfil a legitimate objective, taking account of the risks non-fulfilment would create', and it then goes on to list examples of 'legitimate objectives', including 'protection of human health or 
safety, animal or plant life or health, or the environment'. Thus a potentially important difference between GATT Article XX and TBT Article 2.2 is that the former includes a closed list of legitimate exceptions which cannot readily be reconciled with social sustainability criteria, whilst TBT Article 2.2 is an open list that specifically mentions 'the prevention of deceptive practices' as a legitimate objective.

Concerns about how environmental and ethical npr-PPMs should be treated in the GATT/WTO are not new. The issue was on the GATT agenda in the early 1970s but little happened (Gonzalez-Garibay, 2011: 175-79). In 1990, during the UR, Mexico raised concerns about restrictions on the import of tuna into the US market, relating to the methods used to fish for tuna and the incidental drowning of dolphins. In the course of its long, but unadopted report, a GATT Panel observed that legislation 'governing the taking of dolphins incidental to the taking of tuna could not possibly affect tuna as a product. Article III:4 therefore obliges the United States to accord treatment to Mexican tuna no less favourable than that accorded to United States tuna, whether or not the incidental taking of dolphins by Mexican vessels corresponds to that of United States vessels' (GATT, 1991: paragraph 5.15).

This ruling came at a time in the GATT when a finding that two products—one with "desirable" npr-PPMs and the other without—were 'like' products brought the matter to a swift conclusion. The Tuna Panel, for example, went on to conclude that the US provisions amounted to a quantitative restriction on trade (prohibited by GATT Article XI) that were not saved by invoking GATT Article XX allowing for derogations from other GATT provisions (GATT, 1991: paragraph 7.1). 
But in subsequent cases of judicial law-making the Appellate Body has softened the WTO's approach to environmental concerns. By 2007 for example Charnovitz (2007) was able to claim that an 'important development for Article XX' has been the willingness of the Appellate Body to 'cast aside some of the GATT and early WTO panel holdings that threatened to render the environmental exceptions unusable.' In what is likely to become another landmark case of judicial law-making, Mexico in Tuna II again challenged US measures relating to the accidental drowning of dolphins when fishing for tuna. Although the contested policy measures — fishing for tuna-were clearly npr-PPMs, and formed much of the substance of the evidence considered by the Panel and the Appellate Body, the legal complaint ('the measure at issue') was 'the US dolphin-safe labelling provisions' (WTO, 2012: paragraph 2). Having determined that the measure at issue was a technical regulation within the coverage of the TBT Agreement, the Panel arbitrated the dispute under the TBT Agreement. Mexico, however, had also challenged the US measure under GATT Articles I and III. On appeal the Appellate Body expressed its view that the Panel had engaged in 'false judicial economy,' in part because 'the assumption that the obligations under Article 2.1 of the TBT Agreement and Articles I:1 and III:4 of the GATT 1994 are substantially the same' is incorrect (WTO 2012: paragraph 405).

It was found that Mexican tuna products were like 'tuna products of United States' origin', and that "the US "dolphin-safe" labelling provisions provide[d] "less favourable treatment" to Mexican tuna products than that accorded to tuna products of the United States ...' (WTO, 2012: paragraphs $202 \&$ 299). Less favourable treatment could be justified however on the basis of two legitimate objectives within the meaning of Article 2.2 TBT: 'ensuring that consumers are not misled or deceived about whether tuna products contain tuna that was caught in a manner that adversely affects dolphins' and 'contributing to the protection of 
dolphins, by ensuring that the US market is not used to encourage fishing fleets to catch tuna in a manner that adversely affects dolphins' (WTO 2012: paragraphs 302 and 407).

Moreover, the Appellate Body decided that 'the measure at issue' was not 'more trade restrictive than necessary to fulfil the United States' legitimate objectives, taking account of the risks non-fulfilment would create' (WTO 2012: paragraph 331). Similarly, in EC-Seal Products, the panel concluded 'that the EU Seal Regime is a technical regulation and that the EU Seal Regime does not violate Article 2.2 of the TBT Agreement because it fulfils the objective of addressing EU public moral concerns on seal welfare to a certain extent, and no alternative measure was demonstrated to make an equivalent or greater contribution to the fulfilment of the objective'. ${ }^{1}$

From a historical institutionalist perspective it is interesting to observe that the institutional practices related to the GATT and TBT agreements are evolving. Thus, whilst doubts had been expressed about the applicability of the TBT Agreement to npr-PPMs, in Tuna II nprPPMs were, in effect, successfully addressed and defended in relation to environmental concerns. This, however, cannot be interpreted as a substantial institutional change. Rather, it is a bounded change since the ruling was still founded on the basic principle of free trade and consequently the legal deliberation revolved around whether or not, and to what extent, the environmental measures were trade discriminating. Nevertheless, this development in the legal interpretation of the trade rules related to environmental measures can be expected to empower environmental interests in domestic trade-related environmental policy making.

While the legal interpretations in relation to environmental sustainability had become less strict, the social dimension of the sustainability concept remained unclear in the late 2000 s. Though labour rights conditionality can be found in some trade policies, they have never 
been challenged in the WTO (Kolben 2010); and they never became a part of the GATT or WTO agenda (Gonzalez-Garibay 2011: 172). GATT Article XX's closed list of exceptions offered little scope for legitimizing social sustainability criteria, but if the measure in question is a technical regulation subject to the disciplines of the TBT Agreement, then it may be possible to build a WTO defence of such criteria.

\section{DEVELOPING THE EU BIOFUELS POLICY IN THE SHADOW OF THE WTO}

This section analyses how the WTO legal framework influenced the dynamics of the debate in the EU leading to adoption of the EU's revised Fuel Quality Directive and a new Renewable Energy Directive in 2009 (Swinbank and Daugbjerg 2013). ${ }^{2}$ The three most important policy-making institutions in the EU are the European Commission (formerly the Commission of the European Communities), the Council of Ministers representing the 28 Member States, and the directly-elected EP. The Commission has the right of initiative. For the legislation discussed in this article, the Council and EP have joint decision-making authority in a process commonly known as co-decision.

The EU, and its Member States, had for some time been developing its policies to encourage the uptake of biofuels, but a new phase was launched in An EU Strategy for Biofuels that talked about the need to develop 'sustainable biofuel production' (Commission of the European Communities, 2006: 4). While various aspects of sustainability were raised by NGOs and other policy advocates in a Public Consultation in 2007, it was the debate in the EP that re-introduced social sustainability onto the agenda despite WTO concerns expressed by the Commission and several Member States. This then is a useful case study of how in the late 2000s WTO trade rules influenced the dynamics of domestic policy processes. 
The environmental sustainability criteria that governments have introduced to differentiate between biofuels that can count under renewable energy programmes, and those that cannot, are npr-PPMs. The international convention is that when biofuels are used they have zero GHG emissions, based on the assumption that the growing plant has absorbed an equivalent amount of $\mathrm{CO}_{2}$. In cultivating, harvesting, processing and distributing the biofuel, however, GHGs are emitted. Furthermore if new land is brought into cultivation to produce the biomass, carbon might be released from the soil or the natural vegetation (particularly trees) thus reducing, if not negating, the apparent saving in GHG emissions. Consequently the EU developed a complex methodology to determine the life cycle GHG emission savings of any particular biofuel, and it is only if this paper trail can demonstrate a GHG emissions saving of at least $35 \%$ (but set to rise to $60 \%$ ) compared to fossil fuel that this biofuel is deemed compliant. Swinbank and Daugbjerg (2013) considered this npr-PPM to be particularly problematic in the WTO, as suppliers that marginally fail the test are liable to protest that their non-compliant biofuel is 'like' a compliant biofuel.

In a further attempt to ensure that land with a high carbon stock had not been cleared to grow biofuels, the EU also insists that compliant biofuels must not be grown on land that had this characteristic in January 2008. A third npr-PPM extends this principle to land that had high levels of biodiversity in January 2008, reflecting concerns that an expansion of the production of biomass for biofuel could result in widespread environmental devastation. As yet EU legislation only addresses direct land-use change. Controversy surrounds indirect land use change (ILUC) and how it might be addressed. Most biofuels today are so-called first generation fuels produced from crops that are commonly used as food or animal feed (cereals, sugar, vegetable oils). As the demand for biofuels increase, driven by government support, the price of these food commodities is likely to increase, leading to concerns about 
the impact on world food prices, and new land is likely to be brought into cultivation to replace the food and fibre crops that the biofuels displaced. Thus this ILUC can result in the loss of carbon sinks (e.g. forests) and biodiversity.

While the WTO agreements were not viewed as a constraint by EU policy makers when including the aforementioned environmental sustainability measures in its biofuels policy (although they could potentially be challenged within the WTO Dispute Settlement system), WTO trade rules were seen as an impediment to the introduction of binding social sustainability measures. Members of the European Parliament (MEPs) had from time to time suggested that a social clause should be included in trade rules. For example in the closing phases of the UR they passed a resolution urging, inter alia, the EU 'to ensure that the Declaration of the Ministerial Conference closing the Uruguay Round contains a commitment and specific agreements to achieve this priority objective' (European Parliament 1994: paragraph 6), but to no avail. The issue of social sustainability in the EU's policies reemerged as a political concern in 2007 in the debate on amendments to the Fuel Quality Directive. The Environment, Public Health and Food Safety Committee (ENVI) in the EP had expressed a wish to include social sustainability criteria in the Directive. A report commissioned by the Committee concluded, however, that 'Inclusion of broader sustainability criteria (outside greenhouse gas emission) within the Fuel Quality Directive would probably not be accepted within the WTO framework' (Stans et al. 2007: 20). Despite this, as the biofuel dossiers progressed, social sustainability criteria were broadly discussed. The impacts of biofuels production on global food prices and security, displacement of small farmers and indigenous people, poor working conditions in developing countries, child labour and respects for human rights, were repeatedly raised by MEPs and NGOs. ${ }^{3}$ For instance Biofuelwatch (2007: 1) wrote in its submission to the 2007 Consultation: 
... the European Commission's proposal completely ignores social criteria. Under those proposals, biofuels produced at the expense of indigenous and other local communities, those linked to human rights abuses, evictions and impoverishment, or to loss of food security could still attract public support as 'sustainable biofuels'. This is not acceptable. There is growing evidence of human rights abuses and evictions linked to biofuel production, for example in Indonesia, Colombia, Brazil and Paraguay.

In January 2008, the EU Commission launched its Climate Change Package including proposals for a Renewable Energy Directive (RED) (Commission of the European Communities 2008). There was no reference to social sustainability criteria, world food prices, or indirect land-use change in the proposal, other than committing the Commission to 'monitor the commodity price changes associated with the use of biomass for energy and any associated positive and negative effects on food security' (Draft Article 20). Within the Commission 'it was felt ... that [compulsory labour standards] would overstep some countries “red lines' and thus would almost certainly trigger an action in the WTO' (Ackrill and Kay 2011: 560). While France pushed for more emphasis on social criteria (US Mission to European Union 2008b), the United Kingdom and The Netherlands were concerned that sustainability criteria, including social criteria, could lead to litigation in the WTO (EurActiv, 'EU deal on biofuels remains distant', 8 June 2008). The Commission repeated its concern about including mandatory social sustainability criteria in the RED as '.. social issues and food security were not seen by the Commission as workable criteria, as they are seen as difficult to link to individual consignments of biofuel, and may raise issues under world trade law' (Agra Europe, 2329, 26 September 2008, EP/6-7). 
The EP made the Committee on Industry, Research and Energy (ITRE) responsible for the RED proposal, and Claude Turmes (from Luxembourg, a member for the Greens) was appointed rapporteur. The environment committee (ENVI) was designated as the Associated Committee, and Anders Wijkman (a Swedish Christian Democrat with a green profile, and a member of the European People's Party in the EP) appointed draftsman. Since deliberations on the sustainability criteria had already taken place in the ENVI Committee's debate on the Fuel Quality Directive, the draft report that Claude Turmes prepared for his committee in May 2008 made clear he would rely upon the sustainability criteria developed in ENVI, particularly by Dorette Corbey (the rapporteur for the Fuel Quality Directive) and Anders Wijkman. He did, however, write that: 'A set of sustainability criteria has to be enforced ...', including 'Social criteria to protect e.g. small farmers in third world countries' (European Parliament, 2008a: 87).

There were, however, concerns amongst some MEPs that social sustainability criteria might breach WTO rules. When Wijkman produced his draft opinion for ENVI he stated: 'Social criteria were not included in the Commission proposal, one of the reasons given [was] that introducing such criteria could be in conflict with WTO rules'. Apparently endorsing this view he then wrote: 'The proposal of this report is for the Commission to draw up a special report every second year, pertaining to a whole range of social impacts of the increased demand and use of bio-fuels' (European Parliament, 2008c: 7). But he was over-ruled; for Turmes, and fellow Green MEP Marie Anne Isler Béguin, tabled an amendment to Wijkman's draft seeking to include social criteria (European Parliament, 2008e: Amendment 219); and this was reflected in ENVI's Opinion adopted by 36 votes for, with 8 abstentions, on 7 July (European Parliament, 2008d: 51, 79), which then went to the ITRE Committee for consideration. 
As a consequence, in its report of September 2008 (again adopted by a substantial majority, with 50 votes for, and 2 against) the ITRE Committee voted to exclude biofuels that could not meet a series of social sustainability criteria:

(a) the right to use the land can be demonstrated and is not legitimately contested by local communities with demonstrable legal or customary rights;

(b) no raw material must be cultivated on land obtained for that purpose through forced eviction;

(c) the production of raw materials for biofuels ... must not use or support forced labour including bonded labour or child labour as provided for in ILO [International Labour Organization] Conventions 29, 105, 138, 182;

(d) all workers must have legal contracts, must be remunerated fairly and must have, inter alia, the right to organise and bargain collectively and freedom from discrimination as provided for in ILO Conventions 100, 111, 87, 98 (European Parliament 2008b: 114, 344).

In relation to food security, the ITRE Committee suggested an outright prohibition: 'The use of land for the production of biofuels shall not be allowed to compete with the use of land for the production of foods' (European Parliament 2008b: 111).

The threat of a legal challenge in the WTO still loomed. Brazil, along with seven other biofuel-producing states - Argentina, Colombia, Malawi, Mozambique, Sierra Leone, Indonesia and Malaysia - warned on 6 November 2008 that they could 'file a World Trade Organization complaint over what they see as unfair barriers being raised against their 
biofuels'. ${ }^{4}$ The United States apparently shared these concerns (US Mission to European Union 2008b).

Between September and December 2008, Claude Turmes clearly made substantial changes to his text, as a result of the trilogue between the Commission, the Council and Parliament, and yet managed to produce a text acceptable to a clear majority of MEPs, and to the Council of Ministers, which then endorsed it on $1^{\text {st }}$ reading in December 2008. The Commission undoubtedly played an important role in the trilogue, shaping the final outcome. A comparison of what the Commission proposed in February 2008, what ITRE was asking for in September 2008, and what was accepted in December 2008, gives some indication of the relative importance of the perception that social sustainability criteria would be in breach of WTO rules.

In June 2008 the U.S. Mission to the EU (2008a) had reported that in the committee debates: 'Most MEPs were in favor of including some measure of social criteria'. But the December text indicated that MEPs had backtracked, limiting the social sustainability criteria to a reporting commitment for the Commission. Throughout, the Commission argued that its biofuels policy had to be WTO compatible; and it became evident that this concern could not be ignored. A Background Note from the EP's Press Office (European Parliament 2008f: 12) explained:

Parliament's Industry Committee had inserted binding social sustainability criteria, such as respect for the land rights of local communities or the fair remuneration of all workers, into the draft directive. However, as doubts remained about whether such fixed social sustainability criteria were in line with the rules of the World Trade Organisation, the revised text now requires the Commission to monitor the impact of 
the EU's biofuel policy and if necessary propose corrective action, especially if increased biofuels production leads to rising food prices or does not comply with social sustainability criteria.

Thus it would appear that most MEPs had been persuaded that including npr-PPMs relating to social sustainability would risk the EU's entanglement in a trade dispute. Others like Britta Thomsen, spokesperson for the Socialist Group seemed less happy with this outcome. She stated in the parliamentary debate that 'we in the Socialist Group have also stressed the need for social sustainability'. ${ }^{5}$ However, she later claimed that the Greens, who were mainly concerned about environmental sustainability, and non-socialist parties in the EP were not prepared to provide strong support for her wish to include social sustainability as a mandatory criterion in the trilogue negotiations with the Council and Commission (Interview Thomsen, June 2013). This indicates that the uncertainty on how a potential trade dispute would be addressed in the WTO strengthened Wijkman's argument supporting the Commission's reluctance to include social sustainability criteria as a binding requirement, and eventually prevailed amongst the EP's negotiators in the trilogue in which he played an important role.

\section{CONCLUSIONS}

The establishment of the WTO added a new layer to the institutional landscape within which domestic policy is formulated and implemented, and as a result introduced new constraints and opportunities into domestic policy-making. With the Doha Round still ongoing, the current global trade regime by and large reflects the trade policy concerns of the late 1980s and early 1990s, although judicial law-making has led to some development in relation to what are considered to be legitimate environmental policy objectives. 
As the WTO expanded the global trade regime's coverage of behind-the-border measures, a range of domestic policy arenas which had not previously been affected by WTO rules acquired a trade-related dimension. This changed the dynamics of domestic trade-related policy making, constraining some policy agendas while at the same time furthering others. This was for example evident in determining sustainability criteria for biofuels, in particular for the EU in the late 2000s. The prime objective of the EU's biofuels policy is to reduce GHG emissions through the use of raw materials that have been produced in an environmentally sustainable way. To achieve the objective significant imports are required. But sustainability criteria restrict what can profitably be imported. This trade-related dimension of an otherwise domestic policy globalized the context, and policy makers had to take new institutional constraints and opportunities into account. Since similar settings are likely in many other policy fields, the development of the EU's sustainability criteria for biofuels is illustrative for the way in which global institutional constraints and opportunities may influence domestic policy processes and design.

Within the EU there had been political forces wanting to pursue broader social sustainability objectives such as ensuring that the growing of energy crops did not decrease food availability and increase prices in developing countries, and that it did not violate labour rights and the land rights of local communities. These concerns were in particular voiced in the EP. As demonstrated above, an important reason why social sustainability concerns were eventually left out of the mandatory requirements was - it was believed - to ensure WTO compatibility. This perceived influence, rather than a direct effect of a definitive WTO ruling, was an important factor leading EU policy makers - particularly in the EP- to exercise selfrestraint. This was a new and important concern that had tightened constraints on domestic policy making as compared to the pre-1995 GATT regime's rather lax jurisprudence. 
Whether or not subsequent developments in the WTO's jurisprudence (e.g. Tuna II) would have weakened the arguments of those opposed to the inclusion of mandatory social sustainability criteria, and emboldened the EU to include them into the policy design, is a matter for speculation.

Though recent research on how international policy paradigms are transmitted into domestic policy making has significantly progressed our understanding of the dynamics of globalized domestic policy making (e.g. Skogstad 2011), the research agenda is far from exhausted. We have demonstrated that historical institutionalism has significant potential to establish how global institutions may affect domestic policy making. However, such an analysis must be supplemented by an analysis of how the globalization of public policy re-configures domestic policy opportunity structures by furthering some policy agendas and constraining others. The article also demonstrates that conceptual tools developed for studying domestic policy processes need to be rethought and adapted if we are to understand the global impact on domestic policy domains.

\section{Biographical notes}

Carsten Daugbjerg is a professor in the Crawford School of Public Policy, The Australian National University, Australia; and Professor (part-time) in the Department of Food and Resource Economics, University of Copenhagen, Denmark. Alan Swinbank is Emeritus Professor in the School of Agriculture, Policy and Development, University of Reading, United Kingdom.

Addresses for correspondence: Carsten Daugbjerg, Crawford School of Public Policy, The Australian National University, Lennox Crossing, Canberra, ACT 0200, Australia, email: 
carsten.daugbjerg@anu.edu.au / Alan Swinbank, School of Agriculture, Policy and Development, University of Reading, PO Box 237, Reading RG6 6AR, UK, email: $\underline{\text { A.Swinbank@ reading.ac.uk }}$

\section{ACKNOWLEDGEMENT}

Helpful comments from the referees and Editor of this journal, Rob Ackrill, Shona Hawkes, Adrian Kay, Andy Kennedy, Bingqin Li, Matthieu Mondou, Ann Neville, Grace Skogstad and Fiona Yap, were much appreciated. It is output from the research project BIOsoc International and national governance of bioenergy. Funding from the Danish Council for Strategic Research is gratefully acknowledged.

\section{NOTES}

1 Dispute DS401: European Communities — Measures Prohibiting the Importation and Marketing of Seal Products, at http://wto.org/english/tratop_e/dispu_e/cases_e/ds401_e.htm, accessed 27 February 2014.

2 In $2012 / 3$ the EU attempted to revise aspects of its policy, but at the time of writing this initiative is stalled (EurActiv, 'EU governments fail to agree limits on food-based biofuels', 12 December 2013).

3 See for example: Agra Europe, 2244, 2 February 2007, EP/7; 2266, 6 July 2007, EP/5; 2276, 14 September 07, EP/7-8; 2283, 2 November 2007, EP/5; and EurActiv 'NGOs slam draft version of EU biofuel law', 11 January 2008; 'Turmes: Seeks revamped renewables trading, rejects biofuels target', 13 May 2008; 'Biofuels not an obligation, say EU ministers', 7 July 2008; 'Biofuel sustainability deal in sight', 1 September 2008. 
4 http://www.reuters.com/article/2008/11/06/us-eu-biofuels-wto-idUSTRE4A53J620081106, accessed 9 December 2013.

5 http://www.europarl.europa.eu/sides/getDoc.do?pubRef=//EP//TEXT+CRE+20081216+ITEM-010+DOC+XML+VO//EN, accessed 27 March 2013.

\section{REFERENCES}

Ackrill, R. and Kay, A. (2011) 'EU Biofuels Sustainability Standards and Certification Systems - How to Seek WTO-Compatibility', Journal of Agricultural Economics 62(3): 551-64.

Agra Europe, London, weekly, various issues.

Biofuelwatch (2007) Response to the Consultation "Biofuel issues in the new legislation on the promotion of renewable energy", Non-Governmental Organisations' folder: http://ec.europa.eu/energy/renewables/consultations/2007_06_18_biofuels_en.htm (accessed 18 December 2013).

Cerny, P. G. (1997) 'Paradoxes of the Competition State: The Dynamics of Political Globalization, Government and Opposition 32(2): 251-74.

Charnovitz, S. (2007) 'The WTO’s Environmental Progress', Journal of International Economic Law 10(3): 685-706.

Coleman, W. D. and Perl, A. (1999) 'Internationalized Policy Environments and Policy Network Analysis', Political Studies 47(4): 691-709.

Commission of the European Communities (2006) Communication from the Commission: An EU Strategy for Biofuels, COM(2006)34, Brussels: CEC. 
Commission of the European Communities (2008) Proposal for a Directive of the European Parliament and of the Council on the promotion of the use of energy from renewable sources, COM(2008)19, Brussels: CEC.

Daugbjerg, C. and Swinbank, A. (2009) Ideas, Institutions and Trade: The WTO and the Curious Role of EU Farm Policy in Trade Liberalization, Oxford: Oxford University Press.

De Ville, F. (2012) 'European Union regulatory politics in the shadow of the WTO: WTO rules as frame of reference and rhetorical device', Journal of European Public Policy, 19(5): 700-18.

EurActiv, http://www.euractiv.com/, various issues.

European Parliament (1994) 'Social clause in trading system ... Resolution on the introduction of a social clause in the unilateral and multilateral trading system', Official Journal of the European Communities, C61, 28 February, pp. 89-92.

European Parliament (2008a \& b) [Draft] Report on the proposal for a directive of the European Parliament and of the Council on the promotion of the use of energy from renewable sources, Committee on Industry, Research and Energy, Rapporteur Claude Turmes, PE405.949v01 \& v02, Brussels: European Parliament.

European Parliament (2008c \& d) [Draft] Opinion of the Committee on the Environment, Public Health and Food Safety for the Committee on Industry, Research and Energy on the proposal for a directive of the European Parliament and of the Council on the promotion of the use of energy from renewable sources Draftsman: Anders Wijkman, PE406.140v01 \& v02, Brussels: European Parliament.

European Parliament (2008e) Amendments 69 - 304 Draft opinion Anders Wijkman (PE406.140v01-00) on the proposal for a directive of the European Parliament and of 
the Council on the promotion of the use of energy from renewable sources, PE407.817v01, Brussels: European Parliament.

European Parliament (2008f) EP seals climate change package, Background 20081208BKG44004, Brussels: European Parliament.

European Parliament and Council (2009) 'Directive 2009/28/EC of the European Parliament and of the Council of 23 April 2009 on the promotion of the use of energy from renewable sources and amending and subsequently repealing Directives 2001/77/EC and 2003/30/EC', Official Journal of the European Union, L140, 5 June: 16-62.

Finnemore, M. and Sikkink, K. (1998) 'International Norm Dynamics and Political Change', International Organization 52(4): 887-917.

Fioretos, O. (2011) 'Historical Institutionalism in International Relations', International Organization 65(2): 367-99.

GATT (1991) United States - Restrictions on Imports of Tuna. Report of the Panel, DS21/R, Geneva: GATT.

Goldstein, J. L. and Steinberg, R. H. (2008) 'Negotiate or Litigate? Effects of WTO Judicial Delegation on U.S. Trade Politics', Law and Contemporary Problems 71(1): 257-82.

Gonzalez-Garibay, M. (2011) 'The trade-labour and trade-environment linkages: together or apart?', Journal of International Trade Law and Policy 10(2): 165-84.

Haas, P. M. (1992) 'Introduction: epistemic communities and international policy coordination', International Organization, 46(1): 1-36.

Hay, C. (2006) 'Globalization and public policy' in M. Moran, M. Rein and R. Goodin (eds.) The Oxford Handbook of Public Policy, Oxford: Oxford University Press.

Hay, C. and Rosamond, B. (2002) 'Globalization, European integration and the discursive construction of economic imperatives', Journal of European Public Policy, 9(2): 147167. 
Keohane, R. O. (1986) 'Reciprocity in international relations', International Organization 40(1): 1-27.

Kolben, K. (2010) 'The WTO Distraction', Stanford Law \& Policy Review 21: 461-91.

Lydgate, E. B. (2012) 'Biofuels, Sustainability, and Trade-Related Regulatory Chill', Journal of International Economic Law 15(1): 157-80.

March, J. G. and Olsen, J. P. (1989) Rediscovering Institutions: The Organizational Basis of Politics, New York: The Free Press.

Norpoth, J. (2013) 'Mysteries of the TBT Agreement Resolved? Lessons to Learn for Climate Policies and Developing Country Exporters from Recent TBT Disputes', Journal of World Trade 47(3): 575-600.

North, D. C. (1990) Institutions, Institutional Change and Economic Performance, Cambridge: Cambridge University Press.

Pierson, P. (2000a) 'Increasing Returns, Path Dependence and the Study of Politics', American Political Science Review 94(2): 251-267

Pierson, P. (2000b) 'Not Just What, but When: Timing and Sequence in Political Processes' Studies in American Political Development, 14(1): 72-92.

Poletti, A. and De Bièvre, D. (2014) 'Political mobilization, veto players, and WTO litigation: explaining European Union responses in trade disputes,' Journal of European Public Policy, DOI: 10.1080/13501763.2014.897208.

Roundtable on Sustainable Biofuels (2010) RSB Principles \& Criteria for Sustainable Biofuel Production, Version 2, Lausanne: RSB: http://rsb.org/pdfs/standards/11-03-08-RSB-PCsVersion-2.pdf, (accessed 3 January 2013).

Ruggie, J. G. (1982) 'International Regimes, Transactions, and Change: Embedded Liberalism in the Postwar Economic Order', International Organization 36(2): 379415. 
Skogstad, G. (2000) 'Globalization and Public Policy: Situating Canadian Analysis', Canadian Journal of Political Science. 23(4): 805-28.

Skogstad, G. (ed.) (2011) Policy Paradigms, Transnationalism, and Domestic Politics, Toronto: University of Toronto Press.

Stans, J., Ooms, J., Hamelinck, C. and Dehue, B. (2007) Inclusion of Sustainability Criteria in the Fuel Quality Directive, PE 385.651, Policy Department: Economic and Scientific Policy, Brussels: European Parliament.

Stern, N. (2007) The Economics of Climate Change: The Stern Review. Cambridge: Cambridge University Press.

Stone, D. (2008) 'Global Public Policy, Transnational Policy Communities and their Networks', Policy Studies Journal 36(1): 19-38.

Streeck, W. and Thelen, K. (2005) 'Introduction: Institutional Change in Advanced Political Economies', in W. Streeck and K. Thelen (eds.), Beyond Continuity: Institutional Change in Advanced Political Economies, Oxford: Oxford University Press.

Swinbank, A. and Daugbjerg, C. (2013) 'Improving EU Biofuels Policy? Greenhouse Gas Emissions, Policy Efficiency, and WTO Compatibility', Journal of World Trade, 47(4): $813-34$.

Tarasofsky, R. and Palmer, A. (2006) 'The WTO in crisis: lessons learned from the Doha negotiations on the environment', International Affairs 82(5): 899-915.

U.S. Mission to European Union (2008a) 'European Parliament Remains Divided on Commission's Renewables Directive', 19 June, The Public Library of US Diplomacy: https://www.wikileaks.org/plusd/cables/08BRUSSELS940_a.html, (accessed 19 March 2014).

U.S. Mission to European Union (2008b) 'EU Moving Quickly Forward on Biofuels: Windows for Engagement Limited, 8 July, The Public Library of US Diplomacy: 
https://www.wikileaks.org/plusd/cables/08BRUSSELS1171_a.html, (accessed 19 March 2014).

WTO (2012) United States - Measures Concerning the Importation, Marketing and Sale of Tuna and Tuna Products, Report of the Appellate Body, WT/DS381/AB/R, Geneva: WTO. 